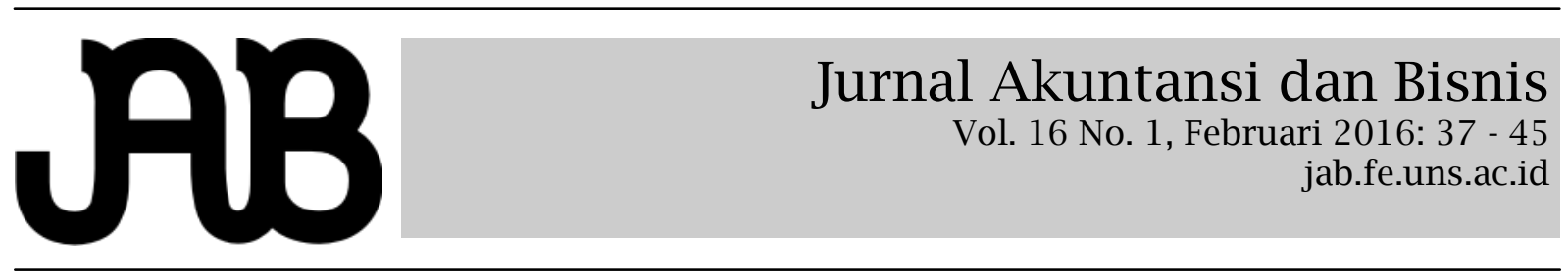

\title{
OPTIMALISASI DANA DESA DENGAN PENGEMBANGAN BADAN USAHA MILIK DESA (BUM Des) MENUJU DESA MANDIRI
}

\author{
PUTRI NUGRAHANINGSIH (pu3alys@yahoo.com) \\ FALIKHATUN \\ JAKA WINARNA
}

Fakultas Ekonomi dan Bisnis Universitas Sebelas Maret

\begin{abstract}
A B S T R A C T
Law of The Republic of Indonesia number 6 of 2014 concerning the village, mandates that the central government allocates fund through transfer mechanism to the Regency/City. Therefore, it is necessary to monitor and evaluate the implementation regarding about the integrity of the law. This study aims to improve the capability and capacity of Village Government apparatus in term management of the Village Fund, to optimize the fund utilization. The method used in this research is descriptive qualitative, data collection techniques include focus group discussions, in-depth interview, observation, and documentation. The place of research in the Bulusulur village, Wonogiri District, Wonogiri Regency, Central Java. The Informant consist of the village head, including the village apparatus, village-owned enterprises (Village BUM) Director, UKM Management Unit, Village Facilitators, and Supervisor of authorities Sub-District and District The results showed that the implementation of village fund is executed with the establishment of Village BUM which has five (5) units Enterprises, that is Keceh Swimming Pool, Campgrounds, Clean Water Facilities, Waste Bank, And Integrated Agriculture. Each business unit has a manager of business unit who is responsible for planning until of reporting. However, in practice there are some constraints such as the difference in the paradigm of the stakeholders associated with the management of the Village Funds, lack of participation of the village community in the implementation of the job program of Village BUM, and a lack of knowledge related to the establishment of work plans and financial statements of Village BUM. The solution that is proposed includes competency enhancement training to Village BUM manager, start from strategic planning, programming, budgeting, implementation, and accompaniment of the Village BUM financial execution.
\end{abstract}

Keywords: village owned enterprises, village fund, independent village, financial execution

Undang-undang Nomor 6 Tahun 2014 tentang Desa mengamanatkan agar pemerintah pusat mengalokasikan Dana Desa melalui mekanisme transfer kepada Kabupaten/ Kota. Untuk itu perlu dilakukan monitoring dan evaluasi agar implementasinya sesuai dengan marwah dari undang-undang tersebut. Penelitian ini bertujuan untuk meningkatkan kapabilitas dan kapasitas aparat Pemerintahan Desa dalam pengelolaan Dana Desa, sehingga pemanfaatan dana tersebut lebih optimal. Metoda penelitian yang digunakan adalah deskriptif kualitatif, dengan teknik pengumpulan data meliputi focus group discussion, in-depth interview, observasi dan dokumentasi. Tempat penelitian di Desa Bulusulur, Kecamatan Wonogiri, Kabupaten Wonogiri, Jawa Tengah. Adapun informan yang dimintai keterangan terdiri dari Kepala Desa, beserta perangkatnya, Direktur BUMDes, Unit Pengelola kelompok UKM, Fasilitator Desa, Aparat pengawas Kecamatan dan Kabupaten. Hasil penelitian menemukan bahwa implementasi Dana Desa dilakukan dengan Pembentukan Badan Usaha Milik Desa (BumDes) yang memiliki lima unit Usaha, yaitu Kolam Keceh, Bumi Perkemahan, Sarana Air Bersih, Bank Sampah, dan Pertanian Terpadu. Masing-masing unit usaha memiliki Manajer Unit Usaha yang bertanggung jawab mulai dari perencanaan sampai dengan pelaporan. Namun dalam pelaksanaannya terdapat beberapa kendala antara lain adanya perbedaan paradigma dari Stakeholder terkait dengan pengelolaan Dana Desa, kurangnya partisipasi masyarakat dalam implementasi program kerja BUMDes, dan kurangnya pengetahuan yang berkaitan dengan pembuatan rencana kerja dan laporan keuangan Bum Des. Adapun solusi yang diusulkan meliputi pelatihan peningkatan kompetensi pengelola BUM Des, mulai dari perencanaan strategis, pemrogramam, penganggaran, implementasi, maupun pendampingan pengelolaan keuangan BUMDes.

Kata kunci: badan usaha milik desa, dana desa, desa mandiri, pengelolaan keuangan 


\section{PENDAHULUAN}

Dana desa dikucurkan pertama kalinya pada Tahun 2015 sesuai amanat UU Nomor 6 Tahun 2014 tentang Desa. Dana ini diharapkan agar dimanfaatkan oleh pemerintah desa untuk membiayai penyelenggaraan pemerintahan, pembangunan, dan pemberdayaan masyarakat desa. Alokasi Dana Desa ini diharapkan mampu mengangkat daerah yang sifatnya susah untuk berkembang sehingga mampu mengejar ketertinggalannya dari daerah lain, namun apakah dengan kondisi desa yang ada sekarang mampu mengelola Dana Desa ini dengan baik?

Berdasarkan amanat UndangUndang Nomor 6 Tahun 2014 tentang Desa dan disertai dengan dikeluarkannya Peraturan Menteri Desa Pembangunan Daerah Tertinggal dan Transmigrasi Nomor 4 Tahun 2015 tentang Pendirian, Pengurusan, Pengelolaan dan Pembubaran Badan Usaha Milik Desa, diharapkan mendorong desa untuk mengelola sumber daya yang ada di desa, termasuk pengembangan ekonomi masyarakatnya. Salah satu cara untuk mengelola ekonomi masyarakat desa adalah dengan dibentuk Badan Usaha Milik Desa (BUMDes). Oleh karena itu, BUMDes wajib untuk melaporkan perkembangan kegiatan BUMDes kepada Pemerintah Daerah.

UU Nomor 6 Tahun 2014 beserta peraturan pelaksanaanya telah mengamanatkan pemerintah desa untuk lebih mandiri dalam mengelola pemerintahan dan berbagai sumber daya alam yang dimiliki, termasuk di dalamnya pengelolaan keuangan dan kekayaan milik desa. Dalam APBN-P 2015 telah dialokasikan Dana Desa sebesar \pm Rp 20,776 triliun kepada seluruh desa yang tersebar di Indonesia. Jumlah desa yang ada saat ini sesuai Permendagri 39 Tahun 2015 sebanyak 74.093 desa (Badan Pengawasan Keuangan dan Pembangunan 2015). Selain Dana Desa, sesuai UU Desa pasal 72, Desa memiliki Pendapatan Asli Desa dan Pendapatan Transfer berupa Alokasi Dana Desa; Bagian dari Hasil Pajak dan Retribusi Kabupaten/Kota; dan Bantuan Keuangan dari APBD Provinsi/ Kabupaten/Kota. Peran besar yang diterima oleh desa, tentunya disertai dengan tanggung jawab yang besar pula. Oleh karena itu pemerintah desa harus bisa menerapkan prinsip akuntabilitas dalam tata pemerintahannya, dimana semua akhir kegiatan penyelenggaraan pemerintahan desa harus dapat dipertanggungjawabkan kepada masyarakat desa sesuai dengan ketentuan.

Dalam hal keuangan desa, pemerintah desa wajib menyusun Laporan Realisasi Pelaksanaan APB Desa dan Laporan Pertanggungjawaban Realisasi Pelaksanaan APB Desa. Laporan ini dihasilkan dari suatu siklus pengelolaan keuangan desa, yang dimulai dari tahapan perencanaan dan penganggaran; pelaksanaan dan penatausahaan; hingga pelaporan dan pertanggungjawaban pengelolaan keuangan desa.

Dalam tahap perencanaan dan penganggaran, pemerintah desa harus melibatkan masyarakat desa yang direpresentasikan oleh Badan Permusyawaratan Desa (BPD), sehingga program kerja dan kegiatan yang disusun dapat mengakomodir kepentingan dan kebutuhan masyarakat desa serta sesuai dengan kemampuan yang dimiliki oleh desa tersebut. Selain itu pemerintah desa harus bisa menyelenggarakan pencatatan, atau minimal melakukan pembukuan atas transaksi keuangannya sebagai wujud pertanggungjawaban keuangan yang dilakukannya.

Namun demikian, peran dan tanggung jawab yang diterima oleh desa belum diimbangi dengan sumber daya manusia (SDM) yang memadai baik dari segi kuantitas maupun kualitas. Kendala umum lainnya yaitu desa belum memiliki prosedur serta dukungan sarana dan prasarana dalam pengelolaan keuangannya serta belum kritisnya masyarakat atas pengelolaan anggaran pendapatan dan belanja desa. Besarnya dana yang harus dikelola oleh pemerintah desa memiliki risiko yang cukup tinggi dalam pengelolaannya, khususnya bagi aparatur pemerintah desa.

Dalam Undang-undang Nomor 12 tahun 2008 perubahan atas Undang-undang Nomor 32 tahun 2004 tentang Pemerintahan Daerah pada Pasal 213 ayat (1) disebutkan bahwa "Desa dapat mendirikan badan usaha milik desa sesuai dengan kebutuhan 
dan potensi desa. Logika pendirian BUMDes didasarkan pada kebutuhan dan potensi desa, sebagai upaya peningkatan kesejahteraan masyarakat. Berkenaan dengan perencanaan dan pendiriannya, BUMDes dibangun atas prakarsa (inisiasi) masyarakat, serta mendasarkan pada prinsipprinsip kooperatif, partisipatif, (user-owned, user-benefited, and user-controlled), transparansi, emansipatif, akuntabel, dan sustainable dengan mekanisme member-base dan self-help. Dari semua itu yang terpenting adalah bahwa pengelolaan BUMDes harus dilakukan secara profesional dan mandiri.

Sesuai dengan amanat Undangundang Nomor 6 Tahun 2014 tentang Desa, Pemerintah akan mengalokasikan Dana Desa, melalui mekanisme transfer kepada Kabupaten/Kota. Penelitian ini dilaksanakan atas dasar penelitian-penelitian sebelumnya yang membahas mengenai pengelolaan keuangan dana desa dan alokasinya yang merupakan keseluruhan kegiatan yang meliputi perencanaan, pelaksanaan, penatausahaan, pelaporan, dan pertanggungjawaban keuangan desa.

Dalam pemberdayaan masyarakat pedesaan diperlukan konsistensi. Hal itu harus menjadi konsepsi yang benar-benar memungkinkan masyarakat pedesaan untuk dapat bertahan dalam situasi perekonomian yang serba sulit seperti saat ini. Selain itu, meningkatkan harkat dan martabat serta kemampuan dan kemandirian yang nantinya dapat menciptakan suasana kondusif. Jadi, hal itu memungkinkan masyarakat pedesaan untuk berkembang dan memperkuat daya saing serta potensi yang dimiliki. Pemberdayaan masyarakat pedesaan juga harus mampu memberikan perlindungan yang jelas terhadap masyarakat.

Berdasarkan kondisi existing desa, masih banyak kendala ditemukan dalam pelaksanaannya diantaranya, masih terdapat desa yang belum menyusun Anggaran Pendapatan dan Belanja Desa (APBDesa), kurangnya kompetensi Tim Pelaksana Kegiatan Desa dalam menyusun laporan pertanggungjawaban alokasi dana desa sebagai bagian pelaksanaan rencana pembangunan, bentuk partisipasi masyarakat yang kurang maksimal, serta kurangnya partisipasi Badan Permusyawaratan Desa (BPD).

Tujuan penelitian ini adalah memastikan seluruh ketentuan dan kebijakan keuangan dan Pembangunan Desa dilaksanakan dengan baik sehingga pemanfaatan dana desa menjadi lebih optimal. Ruang Lingkupnya meliputi kebijakan keuangan dan pembangunan desa beserta implementasi dana desa dengan pembentukan Badan Usaha Milik Desa (BUMDes) oleh Pemerintah Desa.

\section{TINJAUAN PUSTAKA \\ Definisi Desa}

Berdasarkan UU Nomor 6 Tahun 2014, pasal 1 ayat 1 dinyatakan bahwa desa adalah desa dan desa adat atau yang disebut dengan nama lain, selanjutnya disebut Desa, adalah kesatuan masyarakat hukum yang memiliki batas wilayah yang berwenang untuk mengatur dan mengurus urusan pemerintahan, kepentingan masyarakat setempat berdasarkan prakarsa masyarakat, hak asal usul, dan/atau hak tradisional yang diakui dan dihormati dalam sistem pemerintahan Negara Kesatuan Republik Indonesia sedangkan pengertian Pemerintahan Desa adalah penyelenggaraan urusan pemerintahan dan kepentingan masyarakat setempat dalam sistem pemerintahan Negara Kesatuan Republik Indonesia. Desa berkedudukan di wilayah kabupaten/kota.

Pemerintah desa menggunakan dana APB Desa untuk membiayai pelaksanaan kewenangan desa dalam bentuk berbagai kegiatan pembangunan dan pemberdayaan masyarakat desa. Selain itu pemerintah desa wajib menyelenggarakan pengelolaan keuangan dengan tertib dan sesuai dengan ketentuan.

\section{Dana Desa}

Berdasarkan UU Nomor 6 Tahun 2014, Dana Desa adalah dana yang bersumber dari Anggaran Pendapatan dan Belanja Negara yang diperuntukkan bagi Desa yang ditransfer melalui Anggaran Pendapatan dan Belanja Daerah Kabupaten/Kota dan digunakan untuk membiayai penyelenggaraan pemerintahan, pelaksanaan pem- 
bangunan, pembinaan kemasyarakatan, dan pemberdayaan masyarakat.

\section{Badan Usaha Milik Desa (BUMDes)}

Berdasarkan UU Nomor 6 Tahun 2014, Pasal 1, Badan Usaha Milik Desa, yang selanjutnya disebut BUMDes adalah badan usaha yang seluruh atau sebagian besar modalnya dimiliki oleh Desa melalui penyertaan secara langsung yang berasal dari kekayaan Desa yang dipisahkan guna mengelola aset, jasa pelayanan, dan usaha lainnya untuk sebesar-besarnya kesejahteraan masyarakat Desa. BUMDes merupakan pilar kegiatan ekonomi di desa yang berfungsi sebagai lembaga sosial (social institution) dan lembaga komersial (commercial institution). BUMDes sebagai lembaga sosial berpihak kepada kepentingan masyarakat melalui kontribusinya dalam penyediaan pelayanan sosial sedangkan sebagai lembaga komersial bertujuan mencari keuntungan melalui penawaran sumberdaya lokal (barang dan jasa) ke pasar.

BUMDes sebagai suatu lembaga ekonomi modal usahanya dibangun atas inisiatif masyarakat dan menganut asas mandiri. Ini berarti pemenuhan modal usaha BUMDes harus bersumber dari masyarakat. Meskipun demikian, tidak menutup kemungkinan BUMDes dapat mengajukan pinjaman modal kepada pihak luar, seperti dari Pemerintah Desa atau pihak lain, bahkan melalui pihak ketiga. Penjelasan ini sangat penting untuk mempersiapkan pendirian BUMDes, karena implikasinya akan bersentuhan dengan pengaturannya dalam Peraturan Daerah (Perda) maupun Peraturan Desa (Perdes). Berikut ini karakteristik BUMDes (Kurnia 2015).

Terdapat 7 ciri utama yang membedakan BUMDes dengan lembaga ekonomi komersial pada umumnya yaitu:

1. Badan usaha ini dimiliki oleh desa dan dikelola secara bersama;

2. Modal usaha bersumber dari desa (51\%) dan dari masyarakat (49\%) melalui penyertaan modal (saham atau andil);

3. Operasionalisasinya menggunakan falsafah bisnis yang berakar dari budaya lokal (local wisdom);
4. Bidang usaha yang dijalankan didasarkan pada potensi dan hasil informasi pasar;

5. Keuntungan yang diperoleh ditujukan untuk meningkatkan kesejahteraan anggota (penyerta modal) dan masyarakat melalui kebijakan desa (village policy);

6. Difasilitasi oleh Pemerintah, Pemprov, Pemkab, dan Pemdes;

7. Pelaksanaan operasionalisasi dikontrol secara bersama (Pemdes, BPD, anggota).

Empat tujuan utama pendirian BUM-

Des adalah meningkatkan perekonomian desa, meningkatkan pendapatan asli desa, meningkatkan pengolahan potensi desa sesuai dengan kebutuhan masyarakat, dan menjadi tulang punggung pertumbuhan dan pemerataan ekonomi pedesaan. BUMDes memiliki 6 karakteristik yaitu berbentuk Badan Hukum, berusaha di bidang perekonomian (jasa, manufaktur, dan perdagangan), modal terdiri dari penyertaan Pemdes dan penyertaan masyarakat dengan perbandingan 51\% dan 49\%, menjadi pusat kegiatan ekonomi masyarakat desa, menjadi salah satu sumber pendapatan Desa, dan memberikan layanan pada masyarakat. Usaha yang dapat dijalankan melalui BUMDes yaitu pasar desa, waserda, transportasi, industri rumahan (home industry), perikanan darat, pertanian, simpan pinjam, sumber air, obyek wisata desa, kerajinan rakyat, peternakan, dan agroindustri.

\section{Sistem Informasi Akuntansi BUMDes}

BUMDes merupakan lembaga ekonomi desa yang bersifat terbuka. Untuk itu, diperlukan penyusunan desain sistem pemberian informasi kinerja BUMDes dan aktivitas lain yang memiliki hubungan dengan kepentingan masyarakat umum sehingga keberadaannya sebagai lembaga ekonomi desa memperoleh dukungan dari banyak pihak.

Secara umum, prinsip pembukuan keuangan BUMDes tidak berbeda dengan pembukuan keuangan lembaga lain pada umumnya. BUMDes harus melakukan pencatatan atau pembukuan yang ditulis secara sistematis dari transaksi yang terjadi setiap hari. Pencatatan transaksi itu umumnya menggunakan sistem akuntansi. 
Fungsi dari akuntansi adalah untuk menyajikan informasi keuangan kepada pihak internal dan eksternal dan sebagai dasar membuat keputusan. Pihak internal BUMDes adalah pengelola dan Dewan Komisaris, sedangkan pihak eksternal adalah pemerintah kabupaten, perbankan, dan masyarakat yang memberikan penyertaan modal, serta petugas pajak.

Proses pembukuan untuk BUMDes sendiri bisa dilakukan dengan sistem yang diterapkan dalam akuntansi sederhana, yakni dengan membuat dan mengumpulkan bukti transaksi, seperti kwitansi, nota atau bon pembelian maupun penjualan. Dari hasil mengumpulkan bukti transaksi kemudian menyusun buku kas harian atau arus kas (Cash Flow) ke dalam bentuk buku kas harian. Dari Buku Kas Harian ini dapat diketahui berapa besarnya uang masuk dan keluar serta saldo atau sisa dana dalam setiap harinya. Penting untuk dipahami bahwa uang yang keluar tidak lebih besar dari yang masuk agar tidak terjadi defisit.

Untuk memudahkan penggunaan buku harian kas diperlukan membuat sebuah kelompok rekening yang akan memudahkan pengguna laporan keuangan dalam membuat, mengelompokkan dan menyusun pembukuan. Apabila BUMDes mengalami perkembangan sehingga transaksinya bertambah banyak setiap harinya, maka pembukuannya dapat ditambah dengan membuat laporan neraca saldo dan laporan keuangan. Laporan keuangan diperlukan untuk mengetahui kiner- ja keuangan BUMDes secara keseluruhan selama satu periode (biasanya satu tahun). Laporan keuangan akuntansi umum terdiri dari neraca, laporan laba/rugi dan laporan perubahan modal.

\section{METODE PENELITIAN}

Penelitian ini adalah penelitian kualitatif dengan pendekatan deskriptif. Fokus dalam penelitian ini adalah: (1) keberadaan dan kontribusi Badan Usaha Milik Desa (2) pelaksanaan pendampingan pengadministrasian dana desa (3) faktor penghambat dan pendukung keberadaan BUMDes sebagai penguatan ekonomi desa. Lokasi penelitian yang akan dijadikan mitra adalah Desa Bulusulur, Kecamatan Wonogiri.

\section{Jenis dan Sumber Data}

Sumber data yang digunakan dalam penelitian ini adalah sumber data primer dan sekunder. Sumber data primer yaitu data yang diperoleh melalui informan dengan cara melakukan tanya jawab secara langsung dan dipandu dengan pedoman wawancara terstruktur yang sesuai dengan fokus penelitian, yakni Kepala Desa Bulusulur, beserta perangkatnya, Direktur BUMDes, Unit Pengelola kelompok UKM, Fasilitator Desa, Aparat pengawas Kecamatan dan Kabupaten. Sedangkan sumber data sekunder yaitu data yang diperoleh melalui beberapa informasi antara lain dokumen (meliputi profil desa Bulusulur, peraturan-peraturan terkait desa), buku

Tabel 1.

Mitra Desa dan Peran

\begin{tabular}{|c|c|c|}
\hline No & Mitra & Peran \\
\hline \multirow[t]{2}{*}{1} & Desa/ Kelurahan Bulusulur & Desa binaan \\
\hline & Kepala desa & $\begin{array}{l}\text { Kades berperan aktif dalam setiap } \\
\text { pelaksanaan pembangunan yang diadakan } \\
\text { yaitu memimpin pelaksanaan pem- } \\
\text { bangunan }\end{array}$ \\
\hline 2 & Badan Permusyawaratan Desa (BPD) & $\begin{array}{l}\text { Partnership dan koordiantor antara kepala } \\
\text { desa sebagai kepala pemerintah desa dan } \\
\text { BPD sebagai wakil-wakil rakyat desa }\end{array}$ \\
\hline 3 & BUMDes & $\begin{array}{l}\text { Sebagai peran pengusul program atas da- } \\
\text { sar kebutuhan masyarakat dan pengelola } \\
\text { dana desa }\end{array}$ \\
\hline 4 & $\begin{array}{l}\text { Aparat pengawas Kabupaten dan } \\
\text { Kecamatan, Perangkat Desa } \\
\text { (Sekretaris Desa) }\end{array}$ & $\begin{array}{l}\text { Membantu Kepala Desa di bidang Pem- } \\
\text { binaan dan Pelayanan Teknis Administrasi } \\
\text { baik keuangan dan umum }\end{array}$ \\
\hline
\end{tabular}

Sumber: Hasil Wawancara dengan Direktur BUMDes Bulusulur (Mei, 2016) 
teori (ilmiah), dan hasil penelitian (artikel dan jurnal).

\section{Metode Analisis Data}

Pengumpulan data dilakukan melalui teknik focus group discussion, wawancara secara mendalam (in-depth interview), observasi, dan dokumentasi. Analisis data menggunakan analisis interaktif (Huberman dalam Sugiyono 2012) mengemukakan bahwa aktivitas dalam analisis data yaitu pengumpulan data (data collection), reduksi data (data reduction), penyajian data (data display), dan penarikan kesimpulan (conclusion). Metode tersebut dilakukan dengan membandingkan antara hasil wawancara dengan hasil observasi, dan antara hasil wawancara dengan dokumentasi yang diperoleh.

Pelaksanaan program penelitian ini akan dilakukan melalui beberapa tahapan seperti pada Gambar 1, sebagai berikut:

1. Melakukan focus group discussion terkait dengan pengumpulan informasi mengenai keadaan existing profil Desa Bulusulur

2. Koordinasi baik meliputi Pemerintah Desa dan BPD, serta masyarakat dalam proses perencanaan, pelaksanaan, pemanfaatan, dan pemeliharaan hasil-hasil pembangunan.

3. Pengusul dan tim melakukan diskusi review dengan mengimplementasikan Aplikasi Sederhana berbasis Sistem Informasi Akuntansi Pemerintahan Desa dengan pengembangan Aplikasi Sederhana (XLS) \& SIMDes.

4. Pengusul dan tim melakukan Workshop Penyusunan Rencana Pengembangan Desa berbasis sistem informasi akuntansi.

5. Pengusul melakukan bimbingan teknis dan Konsultasi (Bimkon) Pengelolaan Keuangan Desa.

\section{ANALISIS DAN PEMBAHASAN \\ Keberadaan dan Kontribusi BUMDes di Desa Bulusulur}

Salah satu cara untuk mengelola ekonomi masyarakat desa itu adalah dengan dibentuk Badan Usaha Milik Desa (BUMDes). Berdasarkan hasil in-depth interview dan observasi, bahwa optimalisasi dana desa di Bulusulur yaitu dengan implementasi pembentukan Badan Usaha Milik Desa (BUMDes) yang memiliki lima (5) unit Usaha, yaitu 1) Kolam Keceh, 2) Bumi Perkemahan, 3) Sarana Air Bersih, 4) Bank Sampah, dan 5) Pertanian Terpadu. Masing-masing unit usaha memiliki Manajer Unit Usaha yang bertanggung jawab mulai dari perencanaan sampai dengan pelaporan. Kelima Unit Usaha tersebut dipimpin dan dikoordinasikan oleh seorang Direktur BUMDes yaitu Bapak Anggoro. Unit Usaha yang menjadi prioritas utama adalah kolam keceh, bumi perkemahan, dan sarana air bersih. Kolam keceh merupakan sebuah taman setengah jadi terhampar di salah satu kawasan di Dusun Kedungsono, Bulusulur dengan dua kolam renang yang dialiri air kolam jernih dan dingin yang berasal dari sumber air yang berada hanya 3 meter dari kolam kemudian terdapat fasilitas seperti pendapa, panggung, dan fasilitas toilet. Bumi perkemahan juga berada satu lokasi di seputar area bermain dan acara-acara perkemahan sekolah. Selanjutnya, prioritas yang ketiga tepatnya di Dusun Klemud dan Dusun Malangsari yang telah membangun unit usaha Sumber Agung, sejenis PDAM yang memberikan fasilitas air bersih kepada tidak kurang 300 KK. Seperti PDAM umumnya, perusahaan kecil ini juga menarik biaya dari pelanggannya, namun nilainya jauh lebih terjangkau. Pembentukan BUMDes yang ada di desa Bulusulur ini sudah sesuai dengan peraturan desa yang ada dimulai dari dasar hukum yang

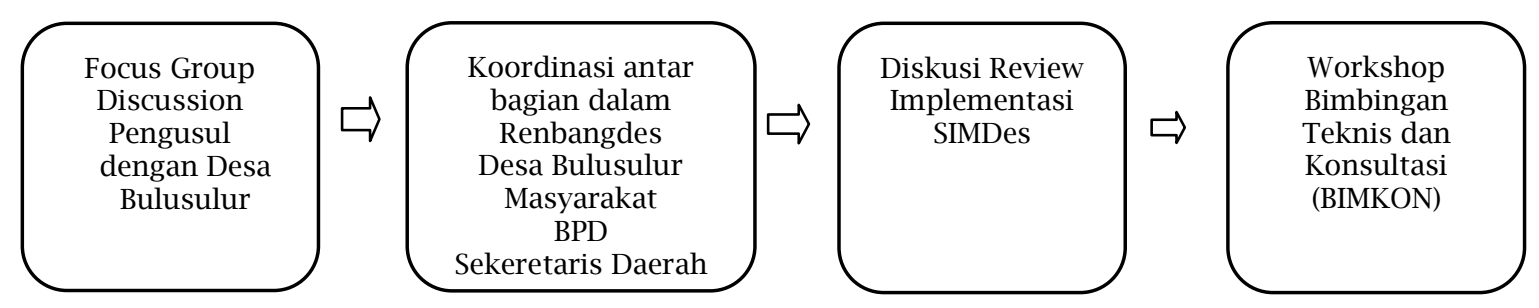

Gambar 1.

Alur Kegiatan Penelitian 
melandasi, anggaran dasar maupun anggaran rumah tangga yang tersusun, dan struktur organisasinya. Mekanisme penyaluran dan pemanfaatan dana ke BUMDes sudah jelas, bahwa dana awal yang dimiliki oleh bumdes ini berasal dari dana hibah yang diberikan oleh pemerintah desa ke badan usaha milik desa. yang ingin memberikan pinjaman modal.

Kontribusi BUMDes dalam rangka kemandirian ekonomi desa, bahwa sumbersumber dana untuk peningkatan pendapatan desa yang diberikan oleh BUMDes masih belum dapat dikatakan memenuhi dan tidak meningkatkan pendapatan desa. Pembangunan desa secara mandiri seharusnya dengan berdirinya badan usaha milik desa ini, desa sudah dianggap menjadi desa yang mandiri. Seharusnya inilah yang menjadi motivasi tersendiri bagi Desa Bulusulur. Akan tetapi yang terjadi di lapangan ialah bahwasanya BUMDes ini juga masih belum berkontribusi penuh sebagai lembaga yang bergerak di bidang ekonomi

\section{Pelaksanaan Pendampingan Pengadminis- trasian Dana Desa}

Khalayak sasaran yang diundang pada pelatihan ini adalah Kepala Desa, beserta perangkatnya, Direktur BUMDes, Unit Pengelola kelompok UKM, Fasilitator Desa, Aparat pengawas Kecamatan dan Kabupaten. Pelaksanaan program penelitian ini akan dilakukan melalui beberapa tahapan. Tahapan tersebut adalah 1) Pemaparan dan diskusi melalui focus group discussion dengan stakeholder terkait dengan pengumpulan informasi mengenai keadaan existing profil dan penyusunan Anggaran Pendapatan dan Belanja Desa (APB-Des) Desa Bulusulur, Wonogiri; 2) Pengusul akan melakukan koordinasi baik meliputi Pemerintah Desa dan BPD, serta masyarakat dalam proses perencanaan, pelaksanaan, pemanfaatan, dan pemeliharaan hasil-hasil pembangunan dana desa; 3) Pengusul dan tim melakukan Workshop Penyusunan Rencana Pengembangan Desa; dan 4) Pengusul melakukan Bimbingan Teknis dan Konsultasi (Bimkon) Pengelolaan Keuangan Desa.

Program pendampingan telah diaplikasikan dengan Kuliah Kerja Nyata (KKN) Te- matik terkait pengadministrasian keuangan desa dan penyusunan laporan keuangan berbasis sistem informasi akuntansi. Dengan langkah awal, menerjunkan mahasiswa ke Desa Bulusulur untuk program KKN Tematik. Hasil KKN Tematik tersebut berupan bagan akun, format laporan keuangan berupa neraca, laporan laba rugi, laporan perubahan modal, buku besar berupa buku kas dan akun-akun terkait dana desa serta laporan gabungan antara beberapa unit BUMDes.

\section{Faktor Penghambat Keberadaan Bumdes}

Bahwa permasalahan teknis ataupun administratif yang teridentifikasi dan menjadi prioritas untuk diselesaikan oleh desa dalam setiap segi sosial dan ekonomi perlu segera diselesaikan adalah:

a. Proses perencanaan yang tidak memadai, misalnya tidak melibatkan semua aspek/elemen desa, maka perencanaan penggunaan Dana Desa tidak optimal mengakomodasi kebutuhan desa. Upaya menggali potensi desa menjadi gagal.

b. Perbedaan paradigma diantara stakeholder desa terhadap apa yang telah direncanakan, pemahaman (interpretasi) bagaimana mengelola atau menggunakan Dana Desa tidak sama antara satu pihak dengan pihak yang lain.

c. Muncul potensi pengelolaan atau penggunaan dana desa tidak sesuai petunjuk teknis dan petunjuk pelaksanaan dapat terjadi, dan pada akhirnya penyimpangan pelaksanaan terjadi.

d. Dalam hal pencatatan keuangan, kesiapan SDM BUMDes dalam menyusun pelaporan keuangan belum memadai, para pengelola unit usaha belum sepenuhnya memahami pengklasifikasian transaksi dan pos-pos (akun) laporan keuangan.

e. Aspek-aspek yang harus diawasi dalam pengelolaan Dana Desa belum begitu jelas meskipun telah diatur dalam Undang-Undang Desa Nomor 6 tahun 2014 seperti halnya, petunjuk manual dan software resmi terkait pengadministrasian dana desa dari Pemerintah Pusat belum ada panduan dan peraturan khususnya terkait pelaporan keuangan dana desa. 
f. Implementasi pengawasan Dana Desa belum dapat diketahui secara teknis, sehingga masih ada kekhawatiran apakah pelaksanaan pengawasan ini mampu mengawal pelaksanaan Dana Desa dijalankan sesuai dengan aturan yang berlaku.

\section{SIMPULAN DAN IMPLIKASI}

Hasil penelitian secara keseluruhan menyimpulkan bahwa pertama, terkait dengan implementasi Dana Desa, maka proses penguatan ekonomi desa melalui BUMDes diharapkan akan lebih berdayaguna. Hal ini disebabkan adanya penopang yakni dana anggaran desa yang semakin besar sehingga memungkinkan ketersediaan permodalan yang cukup untuk pendirian BUMDes. Jika ini berlaku sejalan, maka akan terjadi peningkatan Pendapatan Asli Desa (PADesa) yang selanjutnya dapat digunakan untuk kegiatan pembangunan desa. Kedua, BUMDes harus dikelola secara profesional dan mandiri sehingga diperlukan orang-orang yang memiliki kompetensi untuk mengelolanya. Setiap akhir periode tahun anggaran, pengelola wajib menyusun laporan pertanggungjawaban untuk disampaikan dalam forum musyawarah desa yang menghadirkan elemen Pemerintahan Desa, elemen masyarakat serta seluruh kelengkapan struktur organisasi BUMDes. Selanjutnya yang ketiga ditemukannya beberapa kendala antara lain adanya perbedaan paradigma dari Stakeholder terkait dengan pengelolaan Dana Desa, kurangnya partisipasi masyarakat dalam implementasi program kerja BUM Des, dan kurangnya pengetahuan yang berkaitan dengan pembuatan rencana kerja dan laporan keuangan Bum Des.

Implikasi penelitian terhadap perkembangan BUMDes menjadikan desa mandiri dan pengelolaan laporan keuangan desa yang akuntabel sehingga mampu meningkatkan pendapatan asli daerah untuk Desa. Ke depannya, Desa mampu menjadi desa teladan dalam pengadministrasian dana desa dan meningkatkan strategi implementasi program pengembangan fasilitas BUMDes Bulusulur yang diminati khalayak umum dan memberikan kemanfaatan bagi masyarakat di wonogiri.

\section{KETERBATASAN DAN SARAN}

Keterbatasan penelitian berupa obyek peneitian masih berfokus di desa Bulusulur belum seluruh desa di Kabupaten Wonogiri. Penelitian hanya berfokus pasa Unit BUMDes, belum mencakup pengelolaan APBDes. Saran yang diusulkan meliputi pelatihan peningkatan kompetensi pengelola BUMDes, mulai dari perencanaan strategis, pemrogramam, penganggaran, implementasi, maupun pendampingan pembuatan keuangan BUMDes.

\section{DAFTAR PUSTAKA}

Badan Pengawasan Keuangan dan Pembangunan. 2015. Petunjuk Pelaksanaan Bimbingan dan Konsultasi Pengelolaan Keuangan Desa (Juklak Bimkon). Available at http:// www.bpkp.go.id

Departemen Pendidikan Nasional. 2007. Buku Panduan Pendirian dan Pengelolaan BUMDes. Malang: PKDSP FE Universitas Brawijaya.

Halim, Abdul. Akuntansi Keuangan Daerah. 2008. Jakarta: Salemba Empat

Kementrian Dalam Negeri. 2010. Petunjuk Teknis Perencanaan Pembangunan Desa, Lampiran Surat Edaran Menteri Dalam Negeri Nomor 414.2/1408/ PMD Tanggal 31 Maret 2010.

Kementrian Dalam Negeri. 2014. Permendagri Nomor 113 Tahun 2014 tentang Pengelolaan Keuangan Desa.

Kurnia, Dadang. 2015. Pengawalan Akuntabilitas Pengelolaan Keuangan Desa. Jakarta: BPKP.

Mardiasmo. 2009. Akuntansi Sektor Publik. Jakarta: CV Andi Offset.

Nordiawan, Deddi, Iswahyudi Sondi Putra, dan Maulidah Rahmawati. 2009. Akuntansi Pemerintahan. Yogyakarta: Salemba Empat.

Republik Indonesia. 2008. UU Nomor 12 Tahun 2008 tentang Pemerintahan Daerah.

Republik Indonesia. 2010. Peraturan Pemerintah Nomor 71 tahun 2010 tentang Standar Akuntansi Pemerintahan.

Republik Indonesia. 2014. Peraturan Pemerintah Nomor 43 Tahun 2014 tentang Peraturan Pelaksanaan Undang-Undang Nomor 6 Tahun 2014 tentang Desa.

Republik Indonesia. 2014. UU Nomor $6 \mathrm{Ta}$ hun 2014 tentang Desa. 
Santri, Premanita. 2015. Akuntabilitas Keuangan Desa: Evaluasi Pengelolaan Alokasi Dana Desa (ADD) di Kabupaten Wonogiri Tahun 2014. Skripsi, Universitas Sebelas Maret, Surakarta.

Sugiyono. 2012. Metode Penelitian Kuantitatif, Kualitatif, dan R\&D. Bandung:
Alfabeta.

Taman, A. et al. 2015. Pelatihan Penyusunan Laporan Keuangan Dana Desa Bagi Perangkat Desa Di Kecamatan Gamping Sleman. Laporan Kegiatan Program Pengabdian pada Masyarakat, Universitas Negeri Yogyakarta, 